Artigos

Volume 9 - $2019 \mid$ n. 21

\title{
Análise dos Recursos Financeiros Aplicados nas Instituições Federais de Educação Profissional, Científica e Tecnológica: 1996-2016
}

\author{
Josué Vidal Pereira \\ Instituto Federal de Goiás (IFGO), Goiânia/GO - Brasil
}

\section{Resumo}

Este estudo teve como objetivo geral a análise das tendências e lógicas do financiamento das Instituições Federais de Educação Profissional, Científica e Tecnológica (EPCT) entre os anos de 1996 e 2016. Os dados levantados indicaram uma mudança de perspectiva de atuação do Fundo Público a partir de 2003. Se, anteriormente, o financiamento público da Educação Profissional (EP) se dava prioritariamente sob o regime de parcerias público-privadas, nesse novo período (2009-2016) o Fundo Público, não obstante tenha mantido o regime de parcerias, ampliou substancialmente o gasto público na modalidade, por meio da criação e da subsequente expansão da Rede Federal de EPCT. De 2009 a 2016 verificou-se a estruturação de uma Rede Federal com capilaridade nacional e marcante processo de interiorização, com substantiva elevação do gasto com Pessoal e Encargos Sociais, de Outras Despesas Correntes e Investimentos.

Palavras-chave: Financiamento da Educação Profissional. Rede Federal de EPCT. Fundo Público.

\section{Analysis of the resources applied in the Brazilian Federal Institutions of Vocational, Scientific and Technological Education: 1996-2016}

\begin{abstract}
The general objective of this study was to analyze the trends and logics of the funding of Brazilian Federal Institutions of Vocational, Scientific and Technological Education (EPCT) from Brazil between 1996 and 2016. The data indicated a change in the action perspective of the Public Fund from 2003 onwards. While the public funding of Vocational Education was previously accomplished under the public-private partnerships regime, in this new period (2009-2016) the Public Fund, despite having maintained the partnership regime, substantially increased public spending in the modality through the creation and subsequent expansion of the EPTC Federal Network. From 2009 to 2016, the structuring of a Federal Network was observed with national capillarity and a remarkable process of interiorization, with a substantial increase in the expenses with Staff and Social Charges, Other Current Expenses and Investments.
\end{abstract}

Keywords: Vocational Education Funding. EPTC Brazilian Federal Network. Public Fund. 
Análise dos Recursos Financeiros Aplicados nas Instituições Federais de Educação Profissional, Científica e Tecnológica

\section{Introdução}

A análise do financiamento da educação no Brasil revela que, desde a reforma do Estado a partir da década de 1990, o processo de inclusão educacional em vários níveis e modalidades se fez acompanhar de uma forte tendência de intensificação da privatização, iniciada durante a ditadura civil-militar. A partir de então parece fortalecer-se o entendimento da educação como serviço/mercadoria, o qual deverá ser adquirido ou financiado pelo próprio indivíduo e pelas famílias. Nesse mesmo contexto chama a atenção as volumosas transferências do fundo público para o setor privado, por meio das quais grande parcela da população tem acesso a uma educação de baixa qualidade, frequentemente custeada com recursos públicos (RODRIGUES, 2017).

A Educação Profissional (EP), embora ainda destinada aos segmentos menos abastados da população, não escapou de tal lógica. Observa-se que, no último decênio, não obstante a ampliação de vagas por meio de diversos programas e políticas de expansão da Rede Pública Federal de Educação Profissional, Científica e Tecnológica, o modelo de financiamento priorizou o setor privado, sobretudo as agências ligadas ao Sistema $S$, tais como Senai, Senac, Sesi etc., as quais ostentam, de acordo com os dados do INEP, tendências crescentes no número de matrículas na modalidade. Ao mesmo tempo, as redes públicas estaduais de educação continuam a ofertar uma educação básica com pouca ou nenhuma articulação com as demandas de formação profissional dos filhos da classe trabalhadora.

A presente pesquisa, que constitui parte da tese de doutoramento do autor, justifica-se pela demanda da produção de conhecimento no campo do financiamento da Educação Profissional, Científica e Tecnológica no Brasil. Conquanto o reconhecido acúmulo de estudos sobre o financiamento da educação básica e superior, a exemplo de Amaral (2003) e Amaral e Pinto (2005), são ainda incipientes os trabalhos dedicados ao financiamento da Educação Profissional e Tecnológica (EPT), com exceção dos estudos de Gabrowski (2010) e Rodrigues (2017), cujos objetos são os programas de EPT desenvolvidos em paralelo ao sistema público orgânico da modalidade.

A histórica tendência do atendimento privado nessa modalidade parece ter sido igualmente seguida pelo "esquecimento" por parte das pesquisas científicas, de modo a obstaculizar o necessário debate em torno do papel do financiamento e das ofertas públicas de EPT, em vista do desenvolvimento social e econômico do País. Nesse sentido, o nosso problema de pesquisa sintetiza-se na seguinte questão: "quais lógicas e tendências constituem o financiamento da Rede Federal de Educação Profissional, Científica e Tecnológica?".

\section{Procedimentos Metodológicos}

Este trabalho tem por objeto o financiamento das Instituições Federais de Educação Profissional, Científica e Tecnológica, em vista de apreender as tendências e lógicas que constituem o seu financiamento entre os anos de 1996 e 2016. Esta pesquisa foi realizada por meio de análise documental, com os dados disponibilizados no Banco de Dados da Execução Orçamentária da União, disponível no sitio eletrônico da Câmara dos Deputados. 
Análise dos Recursos Financeiros Aplicados nas Instituições Federais de Educação Profissional, Científica e Tecnológica

O presente estudo utiliza-se dos pressupostos do materialismo histórico-dialético, em cujas categorias busca-se explicitar as articulações que determinam o movimento do objeto. Nesse sentido, a nossa principal categoria analítica compreende o "financiamento da Rede Federal de Educação Profissional, Científica e Tecnológica”, a partir da qual buscar-se-á compreender o financiamento da educação profissional como uma totalidade histórica articulada, eivada de mediações e reveladora de contradições que determinam a realidade do objeto investigado.

A conceituação do objeto investigado - a Educação Profissional e Tecnológica - foi definida pela LDB $n^{\circ}$ 9.394/1996, posteriormente regulamentada, primeiramente pelo Decreto $n^{\circ} 2.208$ de 17 de abril de 1997, revogado pelo Decreto $n^{\circ} 5.154$ de 23 de julho de 2004 . Mais recentemente verificou-se alterações do texto da LDB sobre a modalidade, através da Lei $n^{\circ}$ 11.741 de 16 de julho de 2008.

O artigo 39 da referida LDB, atualizado pela Lei n 11.741/2008, estabelece a Educação Profissional e Tecnológica como uma modalidade que perpassa os diferentes níveis e modalidades de educação a partir do Ensino Fundamental até a Educação Superior, devendo integrar-se às dimensões do trabalho da ciência e da tecnologia.

\section{O financiamento das Instituições Federais de Educação Profissional, Científica e Tecnológica}

Os recursos destinados ao financiamento das instituições integrantes da Rede Federal de Educação Profissional, Científica e Tecnológica estão registrados nos bancos de dados da Execução Orçamentária da União, no sítio eletrônico da Câmara dos Deputados. Via de regra esses recursos classificam-se em: a) recursos do Tesouro Nacional, oriundos de fontes governamentais decorrentes da arrecadação de impostos, taxas e contribuições; b) recursos próprios, ou seja, diretamente arrecadados pelas instituições, por meio da execução de convênios e/ou contratos com outros organismos públicos ou privados (AMARAL, 2003).

Os grandes blocos de despesas compreendem a totalidade do orçamento da Rede Federal de EPCT. De acordo com o Manual Técnico do Orçamento (BRASIL, 2016), em relação às categorias econômicas, tanto as receitas quanto às despesas são classificadas em duas: despesas correntes e despesas de capital. As despesas correntes são aquelas que não contribuem para a formação ou aquisição de um bem de capital, enquanto as despesas de capital são aquelas que contribuem para a formação ou aquisição de bens de capital.

De acordo com a referida publicação, os grandes blocos de despesas são constituídos por seis grupos em relação à natureza das despesas, dentre os quais os recursos da Rede Federal de Educação Profissional, Científica e Tecnológica (RFEPCT) compreendem os seguintes:

\footnotetext{
1 - Pessoal e Encargos Sociais: Despesas orçamentárias com pessoal ativo, inativo e pensionistas, relativas a mandatos eletivos, cargos, funções ou empregos, civis, militares e de membros de Poder, com quaisquer espécies remuneratórias, tais como vencimentos e vantagens, fixas e variáveis, subsídios, proventos da aposentadoria, reformas e pensões, inclusive adicionais, gratificações, horas extras e vantagens pessoais de qualquer natureza, bem como encargos sociais e contribuições recolhidas pelo ente às entidades de previdência, conforme estabelece o caput do art. 18 da Lei Complementar 101, de 2000.
} 
2 - Outras Despesas Correntes: Despesas orçamentárias com aquisição de material de consumo, pagamento de diárias, contribuições, subvenções, auxílio-alimentação, auxílio-transporte, além de outras despesas da categoria econômica 'Despesas Correntes' não classificáveis nos demais grupos de natureza de despesa.

3 - Investimentos: Despesas orçamentárias com softwares e com o planejamento e a execução de obras, inclusive com a aquisição de imóveis considerados necessários à realização destas últimas, e com a aquisição de instalações, equipamentos e material permanente.

4 - Inversões Financeiras: Despesas orçamentárias com a aquisição de imóveis ou bens de capital já em utilização; aquisição de títulos representativos do capital de empresas ou entidades de qualquer espécie, já constituídas, quando a operação não importe aumento do capital; e com a constituição ou aumento do capital de empresas, além de outras despesas classificáveis neste grupo (BRASIL, 2016, p. 63).

A Tabela 1 apresenta os recursos aplicados na Rede Pública Federal de EPCT, referentes ao conjunto dos grandes blocos de despesas entre os anos de 1996 e 2016, com todas as fontes de receitas.

Tabela 1 - Recursos das Instituições Federais de EPCT, grandes blocos de despesas (1996-2016) com todas as fontes de receitas. Valores em milhares de reais, a preços de janeiro de 2017 (IPCA)

\begin{tabular}{|c|c|c|c|c|c|}
\hline Ano & $\begin{array}{c}\text { Pessoal e } \\
\text { Encargos } \\
\text { Sociais }\end{array}$ & $\begin{array}{c}\text { Outras Despesas } \\
\text { Correntes }\end{array}$ & Investimentos & $\begin{array}{c}\text { Inversões } \\
\text { Financeiras }\end{array}$ & Total \\
\hline 1996 & $1.470 .390,00$ & $322.657,00$ & $94.650,00$ & 996,00 & $1.888 .694,00$ \\
\hline 1997 & $2.086 .028,00$ & $449.918,00$ & $28.949,00$ & 171,00 & $2.565 .068,00$ \\
\hline 1998 & $2.034 .740,00$ & $428.479,00$ & $61.994,00$ & 714,00 & $2.525 .928,00$ \\
\hline 1999 & $2.280 .312,00$ & $442.774,00$ & $34.309,00$ & - & $2.757 .397,00$ \\
\hline 2000 & $2.318 .935,00$ & $450.646,00$ & $33.628,00$ & - & $2.803 .210,00$ \\
\hline 2001 & $2.207 .559,00$ & $432.697,00$ & $28.489,00$ & - & $2.668 .746,00$ \\
\hline 2002 & $2.684 .461,00$ & $401.277,00$ & $30.493,00$ & - & $3.116 .232,00$ \\
\hline 2003 & $2.458 .001,00$ & $373.447,00$ & $37.855,00$ & 242,00 & $2.869 .305,00$ \\
\hline 2004 & $2.637 .597,00$ & $447.361,00$ & $48.712,00$ & - & $3.133 .671,00$ \\
\hline 2005 & $2.458 .025,00$ & $503.910,00$ & $93.802,00$ & - & $3.055 .738,00$ \\
\hline 2006 & $3.148 .529,00$ & $537.192,00$ & $81.535,00$ & - & $3.767 .256,00$ \\
\hline 2007 & $3.332 .715,00$ & $557.264,00$ & $134.398,00$ & - & $4.024 .378,00$ \\
\hline 2008 & $3.664 .842,00$ & $717.713,00$ & $145.868,00$ & - & $4.528 .423,00$ \\
\hline 2009 & $4.476 .411,00$ & $865.533,00$ & $222.398,00$ & - & $5.564 .343,00$ \\
\hline 2010 & $5.392 .019,00$ & $1.461 .116,00$ & $1.153 .548,00$ & - & $8.006 .684,00$ \\
\hline 2011 & $5.996 .559,00$ & $1.886 .347,00$ & $1.504 .508,00$ & - & $9.387 .415,00$ \\
\hline 2012 & $6.653 .487,00$ & $2.229 .082,00$ & $1.566 .827,00$ & 890,00 & $10.450 .287,00$ \\
\hline 2013 & $7.755 .232,00$ & $2.697 .686,00$ & $1.713 .681,00$ & $1.418,00$ & $12.168 .018,00$ \\
\hline 2014 & $9.023 .357,00$ & $2.868 .081,00$ & $1.470 .462,00$ & $19.645,00$ & $13.381 .546,00$ \\
\hline 2015 & $10.303 .491,00$ & $2.441 .862,00$ & $363.467,00$ & $1.668,00$ & $13.110 .490,00$ \\
\hline 2016 & $9.519 .488,00$ & $2.516 .570,00$ & $202.631,00$ & - & $12.238 .690,00$ \\
\hline
\end{tabular}

Fonte: Elaborada pelo autor com informações da Execução Orçamentária da União <www.camara.leg.br>. 
Análise dos Recursos Financeiros Aplicados nas Instituições Federais de Educação Profissional, Científica e Tecnológica

O Gráfico 1 mostra a evolução da totalidade das despesas das Instituições Federais de EPCT, computadas todas as fontes de receitas, entre os anos de 1996 e 2016.

Gráfico 1 - Evolução dos recursos das Instituições Federais de EPCT, total das despesas (19962016) com todas as fontes de receitas. Valores em Reais, a preços de janeiro de 2017 (IPCA)

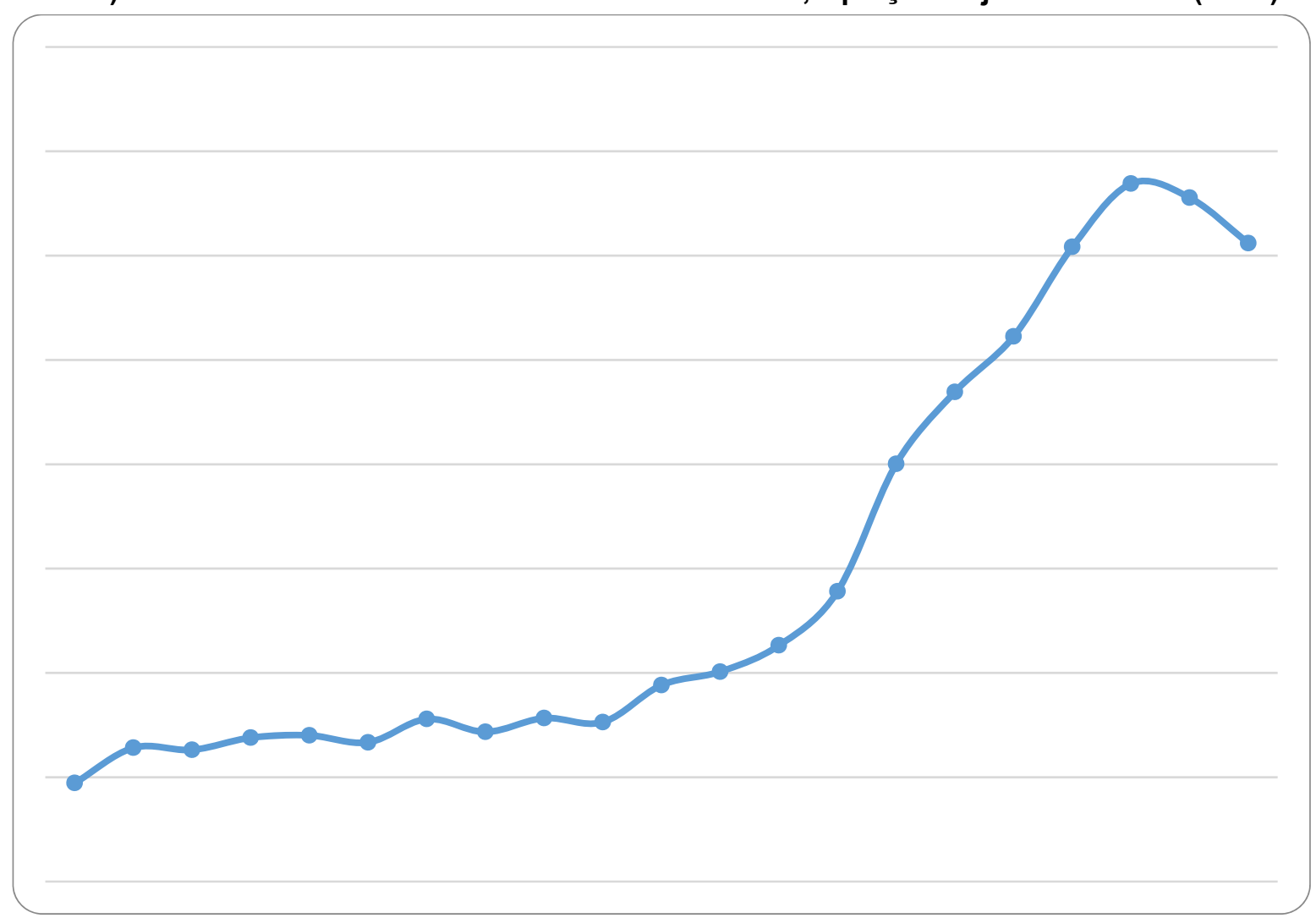

Fonte: Elaborada pelo autor com informações da Execução Orçamentária da União <www.camara.leg.br>.

O Gráfico 1 apresenta uma visão panorâmica da evolução da aplicação dos recursos no conjunto das Instituições Federais de EPCT. A totalidade dos recursos registrados em todos os blocos de despesas indica de fato um extraordinário movimento do aumento do gasto público com o conjunto das instituições, saindo de 1,8 bilhões de reais em 1996 e registrando seu auge em 2014, com 13,3 bilhões de reais, o que significa um crescimento de 7,4 vezes no período. A partir de 2015 observa-se um movimento de redução desses recursos, tendência confirmada em 2016, quando foram aplicados 12 bilhões de reais na Rede Federal de Educação Profissional, Científica e Tecnológica.

A seguir, serão analisados separadamente cada bloco de despesas constituintes do orçamento do conjunto das Instituições. O Gráfico 2 apresenta a evolução das despesas da Rede Federal de Educação Profissional e Tecnológica (RFEPT) (1996-2008) e da Rede Federal de Educação Profissional, Científica e Tecnológica (RFEPCT) referente aos recursos aplicados com Pessoal e Encargos Sociais para o período entre 2009 e 2016. 
Análise dos Recursos Financeiros Aplicados nas Instituições Federais de Educação Profissional, Científica e Tecnológica

\section{Gráfico 2 - Evolução dos recursos da RFEPT e da RFEPCT referente aos recursos aplicados com Pessoal e Encargos Sociais (1996-2016) com todas as fontes de receitas. Valores em reais, a preços de janeiro de 2017 - (IPCA)}

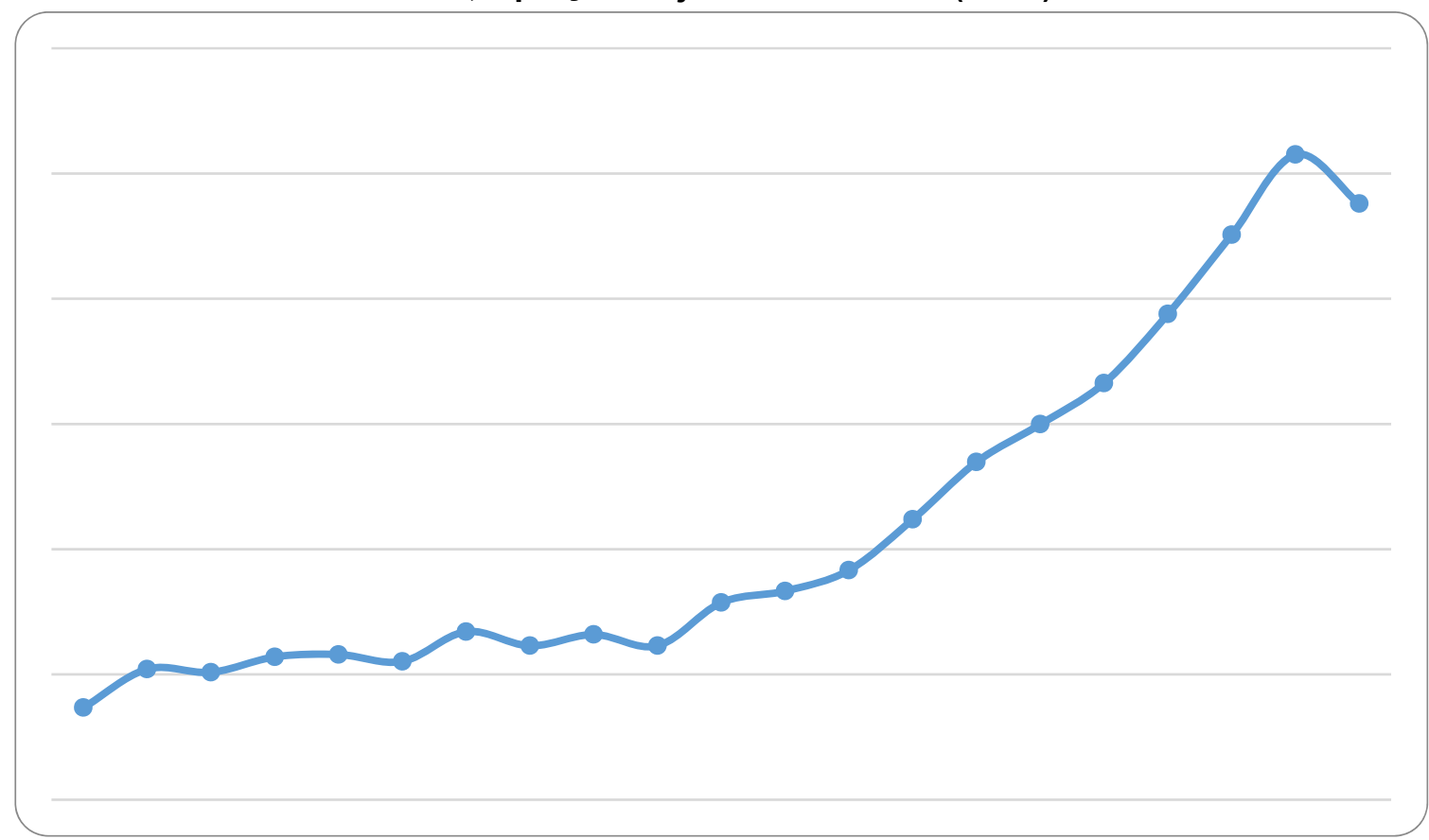

Fonte: Elaborada pelo autor com informações da Execução Orçamentária da União <www.camara.leg.br>.

A análise da Tabela 1 e do Gráfico 2 revela um primeiro aspecto fundamental para a compreensão da aplicação dos recursos financeiros ao longo de toda a série histórica na RFEPT e RFEPCT, qual seja, o quantum de recursos registrados no bloco de despesas de Pessoal e Encargos Sociais. A soma dos recursos aplicados nesse bloco, ao longo do intervalo da pesquisa, revela que $74 \%$ dos recursos de toda a Rede Federal foram direcionados para o pagamento de salários de docentes e pessoal técnico-administrativo, ou seja, a cada 10 reais do orçamento do conjunto das instituições, 7,4 foram registrados nesse bloco de despesas.

Deve-se atentar para o fato de que uma fração expressiva dos trabalhadores das instituições, ou seja, a maior parte da mão de obra ligada aos setores de vigilância, segurança, manutenção, recepção, transporte, reprografia, copeiragem e limpeza, é constituída por terceirizados e são registrados no bloco de Outras Despesas Correntes. Verifica-se ainda, nas instituições criadas antes do processo de reestruturação da Rede, a existência de pessoal efetivo relacionado às áreas supracitadas, cujo número, no entanto, reduz-se gradualmente, uma vez que, após a sua aposentadoria, há uma substituição por terceirizados. A contratação indireta de pessoal pelas Instituições Federais se deu a partir da promulgação do Decreto $\mathrm{n}^{\circ}$ 2.271 de 7 de julho de 1997, durante o governo Fernando Henrique Cardoso. Desde então o quantitativo de pessoal efetivado por concurso público dessas áreas presentes no serviço público vem reduzindo a cada ano.

Convém assinalar, em que pese a economicidade ensejada em favor do Estado pelo processo de terceirização, conforme relatado anteriormente, que é nítida a consolidação de uma dualidade estrutural nas instituições, pela existência de dois grupos distintos de trabalhadores. O primeiro, formado por servidores públicos efetivos, com garantias de 
Análise dos Recursos Financeiros Aplicados nas Instituiç̃es Federais de Educação Profissional, Científica e Tecnológica

permanência e ascensão no serviço público por meio de planos de carreiras, enquanto o segundo grupo é formado por trabalhadores com condições críticas de ocupação, com muito baixo nível de remuneração, alto nível de rotatividade, jornadas extenuantes e com baixa expectativa de progressão funcional. Reproduz-se, desse modo, no seio das Instituições Federais de Educação Profissional e Tecnológica, a lógica hegemônica no contexto da reestruturação produtiva, conforme assinalado por Harvey (2014).

O Gráfico 3 apresenta a dinâmica orçamentária do bloco de Pessoal e Encargos Sociais versus a totalidade dos demais blocos de despesas da RFEPT e da RFEPCT entre os anos de 1996 e 2016.

\section{Gráfico 3 - Dinâmica dos recursos aplicados em Pessoal e Encargos Sociais e Demais Blocos de Despesas (1996-2016) com todas as fontes de receitas. Valores em Reais, a preços de janeiro de 2017 (IPCA)}

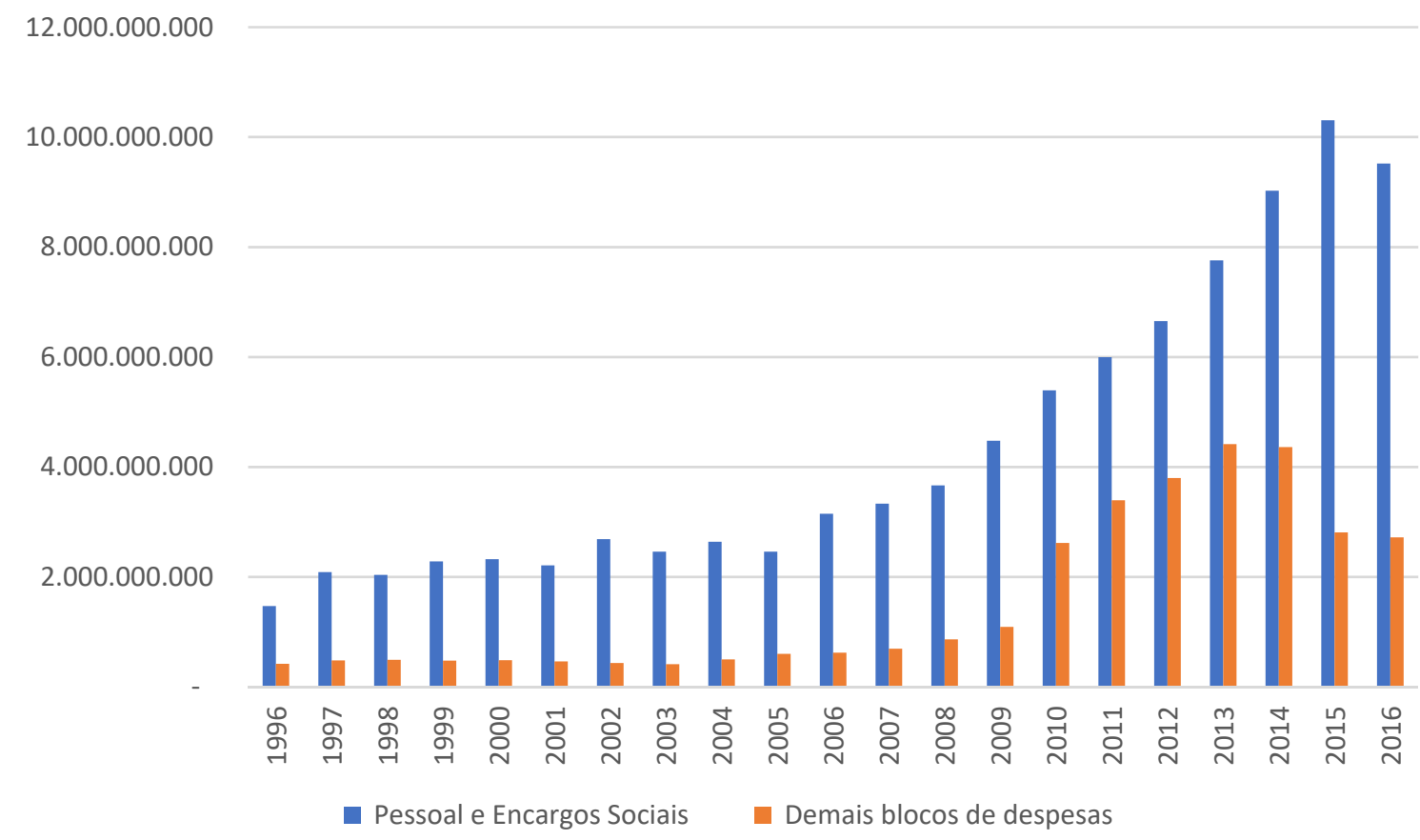

Fonte: Elaborada pelo autor com informações da Execução Orçamentária da União <www.camara.leg.br>

A dinâmica, apresentada no Gráfico 3, indica a existência de duas tendências em relação aos recursos aplicados no bloco de Pessoal e Encargos Sociais. Embora na totalidade esse grupo represente $74 \%$ do total dos recursos, entre os anos de 1996 e 2009 essa diferença é ainda mais expressiva em favor do referido bloco. Nesse intervalo temporal, o menor percentual foi registrado em 1996 - primeiro ano da pesquisa, com $78 \%$ do total dos recursos aplicados. O pico da representatividade desse bloco no conjunto total das despesas ocorre nos anos de 2002 e 2003, com 86\% de participação no total do orçamento anual.

A outra tendência verificada, ao longo da pesquisa em relação à participação desse bloco de despesas, indica importante redução de sua participação no total dos recursos e compreende o período que vai de 2010 a 2014, registrando no primeiro ano $67 \%$, recuando para 64\% entre os anos de 2011, 2012 e 2013 e voltando ao patamar de 67\% no último ano do período. Esse fenômeno, da redução da representatividade do bloco de Pessoal e Encargos Sociais no total do orçamento anual da Rede, ocorre como resultado da 
Análise dos Recursos Financeiros Aplicados nas Instituições Federais de Educação Profissional, Científica e Tecnológica

extraordinária elevação dos recursos do bloco de Investimentos, conforme se verifica na Tabela 1. Com a brusca queda de recursos desse bloco de despesas em 2015 e 2016 e a implantação do mecanismo de certificação, denominado Reconhecimento de Saberes e Competências (RSC), para os docentes efetivos da Rede, verifica-se novamente a tendência anterior de maior participação do bloco de Pessoal e Encargos Sociais, chegando a representar 79\% em 2015 e 78\% no último ano do total do orçamento da Rede Federal de Educação Profissional, Científica e Tecnológica.

Tem-se claro que a análise mais precisa da dinâmica dos recursos aplicados em pessoal e encargos sociais demandaria um estudo exaustivo acerca da evolução das tabelas remuneratórias de docentes e técnico-administrativos das Instituições do conjunto da Rede. No entanto, optamos por apresentar apenas o quadro evolutivo referente à remuneração dos docentes portadores do título de Mestre, com remuneração de início de carreira entre os anos de 2002 e 2016, conforme explicitado no Gráfico 4. O propósito nesse sentido é indicar o movimento da aplicação desses recursos para uma fração expressiva do quadro docente da Rede, como forma de representar o movimento geral do período analisado.

A análise da dinâmica remuneratória dos docentes da RFEPT e da RFEPCT, no período supramencionado, embora restrita ao plano ilustrativo, nesse caso por uma subcategoria no interior do Plano de Carreira e Remuneração, qual seja, os professores com titulação de Mestre em início de carreira com Dedicação Exclusiva, indica num primeiro momento que, ao longo da gestão do Partido dos Trabalhadores, em que pese a ampliação do número de servidores públicos contratados em vista da expansão física da Rede, não teria sido implementada uma política efetiva de melhoria nas condições de remuneração do segmento docente.

Gráfico 4 - Evolução dos vencimentos de docentes mestres da RFEPT e da RFEPCT com Dedicação Exclusiva em início de carreira entre 2002 e 2016. Valores em Reais, a preços de janeiro de 2017 (IPCA)

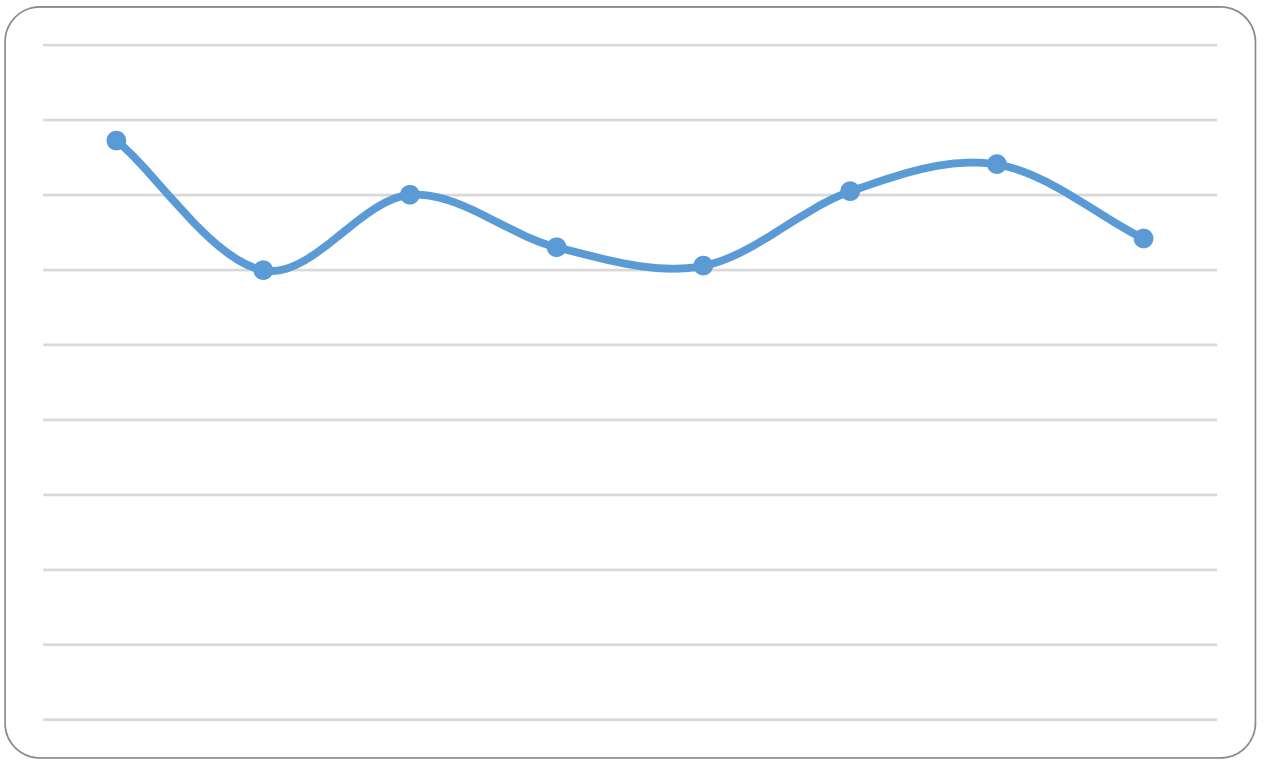

Fonte: IFG (2016); IFSC (2014); IFCATARINENSE (2013); IFMS (2011); MEC (2006).

O movimento registrado no Gráfico 4 indica mesmo uma importante queda na remuneração dos professores durante o primeiro governo Lula (2003-2006). A partir de então 
se verifica um movimento de oscilação que, contudo, ao final de 2016 indicaria uma sensível redução, da ordem de 17\%, do último ano do governo petista em relação ao ano de 2002.

Deve-se, no entanto, ponderar que a análise da evolução da remuneração dos servidores da RFEPT e da RFEPCT precisa considerar as modificações das regras de enquadramento, decorrentes das mudanças nos planos de carreira e salários. Como exemplo do que se afirma tem-se que, na antiga carreira do Magistério de $1^{\circ}$ e $2^{\circ}$ graus, vigente no período anterior à reestruturação da referida Rede, os portadores de títulos stricto sensu iniciavam a carreira enquadrados em classes e níveis intermediários da carreira, enquanto os docentes portadores apenas de graduação ou especialização eram classificados nos níveis e classes iniciais da tabela de progressão.

Pelas regras atuais de enquadramento dos docentes na tabela remuneratória, dadas pela Lei $n^{0} 12.772$ de 28 de dezembro de 2012, o portador de título stricto sensu deve começar sua trajetória como servidor da Rede, no nível mais básico da tabela - D101, de modo que somente após o cumprimento do Estágio Probatório poderá vislumbrar a promoção para a classe D301, que corresponde a oito anos de evolução na carreira de Professor do Ensino Básico, Técnico e Tecnológico (EBTT). Nesse sentido, a instituição do Estágio Probatório, como mecanismo de contenção das progressões para mestres e doutores no início da carreira, representa seguramente grande economicidade para o orçamento institucional e, por consequência, a redução da remuneração docente nos últimos anos em relação às antigas regras de enquadramento.

No entanto, como parte de um movimento contraditório, a já referida Lei $n^{0} 12.772 / 2012$, estabeleceu um conjunto de procedimentos denominados de Reconhecimento de Saberes e Competências, que no âmbito discursivo tinha por objetivo a valorização das trajetórias acadêmicas e profissionais dos docentes. Tal mecanismo permite ao professor da EBTT, portador de determinado título, alçar-se à categoria posterior da respectiva titulação a partir da comprovação documental, conforme consta no Artigo 18 parágrafo $2^{\circ}$ (BRASIL, 2012b):

\footnotetext{
§ $2^{\circ}$ A equivalência do RSC com a titulação acadêmica, exclusivamente para fins de percepção da RT, ocorrerá da seguinte forma:

I - diploma de graduação somado ao RSC-I equivalerá à titulação de especialização;

II - certificado de pós-graduação lato sensu somado ao RSC-II equivalerá a mestrado; e III - titulação de mestre somada ao RSC-III equivalerá a doutorado.
}

Dito de outro modo, no âmbito da Rede Federal de EPCT, diversamente das Universidades Federais, parte expressiva dos docentes, remunerados como doutores, mestres e especialistas, não são de fato portadores dos respectivos títulos, mas de certificação concedida internamente que os equiparam às respectivas titulações acadêmicas para fins remuneratórios.

Com isso, é possível afirmar que o movimento mostrado no Gráfico 4 seguramente não expressa uma realidade objetiva de desvalorização dos servidores docentes da RFEPCT. Por outro lado, embora não se tenham identificado levantamentos oficiais da participação dos servidores com RSC no total da folha de pagamento das Instituições, é possível inferir que a expansão dos recursos de Pessoal e Encargos Sociais, nos últimos anos, está diretamente relacionada à implementação desse mecanismo de certificação. Outro fator que ajuda a explicar tal fenômeno é seguramente o aumento do quadro de servidores docentes e técnicoadministrativos em vista da última fase de expansão da Rede Federal de EPCT, além dos 
reajustes lineares parcelados, conforme estabelece a Lei $n^{\circ} 13.325$ de 29 de julho de 2016; realidade que, no entanto, não é capaz de repor as perdas inflacionárias dos últimos anos.

Ainda em relação à RSC, é importante refletir quanto aos seus efeitos em médio e longo prazos para o desenvolvimento das Instituições. Se, desde já, a sua implementação implica no aumento dos recursos do bloco de Pessoal e Encargos Sociais, é possível inferir - ainda que não se possa mensurar - que, em alguma medida, tal política poderá redundar na diminuição ou economia dos recursos para professores substitutos, uma vez que uma parcela do segmento docente poderá não se sentir devidamente estimulada a buscar a formação continuada em cursos stricto sensu, uma vez que já é contemplada por uma matriz remuneratória correspondente ao nível anteriormente vislumbrado de titulação acadêmica.

Avalia-se, em que pese a tão demandada e necessária valorização dos docentes, que a implementação de uma política com tais características poderá comprometer o papel das Instituições da Rede no que diz respeito, sobretudo, ao desenvolvimento da pesquisa científica e aplicada, que, ao lado do ensino e da extensão, deve constituir o tripé fundamental da construção da identidade institucional, sobretudo por se tratar de uma Rede Pública de Educação Profissional, Científica e Tecnológica.

O Gráfico 5 revela a evolução dos recursos da Rede Federal de EPCT, referentes aos recursos aplicados em Outras Despesas Correntes - tais como água, energia, limpeza, segurança, vigilância, recepção, entre os anos de 1996 e 2016, com todas as fontes de receitas.

Gráfico 5 - Evolução dos recursos da RFEPT e da RFEPCT referente aos recursos aplicados com Outras Despesas Correntes (1996-2016) com todas as fontes de receitas. Valores em reais, a preços de janeiro de 2017 - IPCA

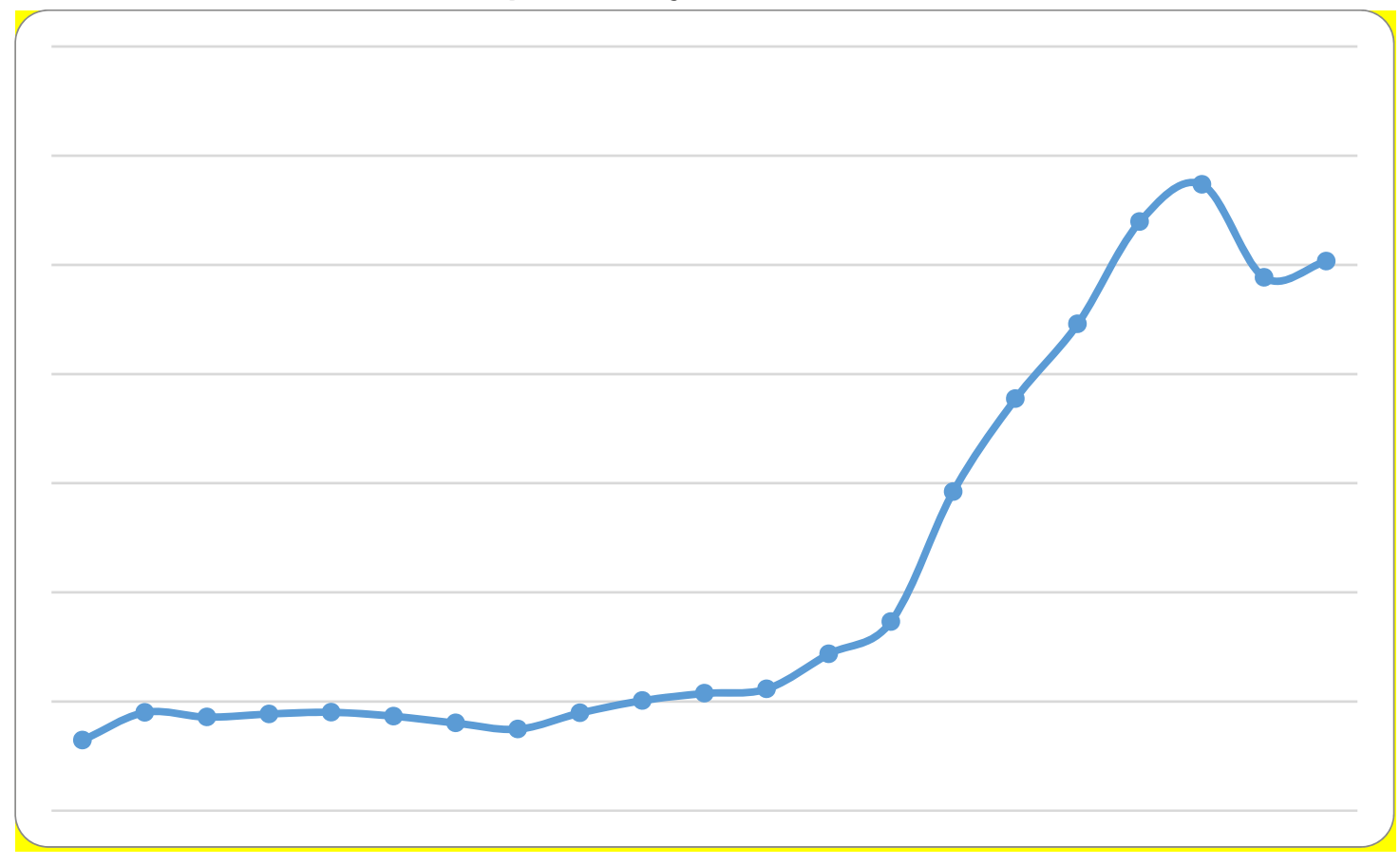

Fonte: Elaborada pelo autor com informações da Execução Orçamentária da União <www.camara.leg.br>.

A dinâmica da aplicação de recursos no bloco de Outras Despesas Correntes demonstra que, entre 1996 a 2005, houve certa estabilidade, com poucos avanços e ligeiros recuos na totalidade dos valores aplicados, registrando, ao longo de 10 anos, apenas 56\% de ampliação. 
Análise dos Recursos Financeiros Aplicados nas Instituições Federais de Educação Profissional, Científica e Tecnológica

Contudo, entre 2005 e 2014 esses recursos apresentaram um salto espetacular de $565 \%$, ou mais de 5,6 vezes do último em relação ao primeiro ano do período, saindo de 503,9 milhões para exponenciais 2,8 bilhões de reais.

Embora, por razões de ordem técnica, seja inviável a apresentação do completo detalhamento dos recursos aplicados no referido bloco, apresentam-se alguns dos elementos de despesas, a fim de que se possa inclusive estabelecer relações entre este e o Bloco de Pessoal e Encargos Sociais.

Os recursos de Proteção e Benefícios ao Trabalhador reúnem três diferentes elementos de despesas, quais sejam: auxílio alimentação, auxílio transporte e assistência pré-escolar. Deve-se ressaltar que, dentre estes, apenas o auxílio alimentação é aplicável a todos os servidores da Rede. Os demais são condicionados pela legislação ao cumprimento de determinadas exigências, o que resulta na não concessão de tais recursos à parte expressiva dos servidores.

A apresentação em bloco dos três elementos de despesas, que constituem os recursos de Proteção e Benefícios ao Trabalhador, inviabiliza uma explicação mais consistente sobre a dinâmica desses recursos, a qual apresentou pouca variação entre os anos de 2000 e 2013 e posteriormente um brusco e enorme salto entre 2013 e 2016 . Seguramente um dos fatores que explica tal ascendência, a partir de 2013, foi o aumento do valor do auxílio alimentação, autorizado pela Portaria n 619 de 26 de dezembro de 2012, que contempla a totalidade dos antigos e novos servidores contratados em vista do processo de expansão da Rede Federal de EPCT - por si só, outro fator de ampliação desse tipo de despesa.

A dinâmica na aplicação de recursos em assistência médica e odontológica para o conjunto dos servidores da Rede Federal de EPCT, no interior do bloco de Outras Despesas Correntes, revela um movimento irregular em relação a outros elementos de despesas já analisados. Primeiramente, entre 2000 e 2005 observa-se um período de estabilidade, no qual é aplicada uma fração ínfima de recursos, que no auge do período chega a 2 milhões de reais, em 2004. A partir de 2005 esse elemento de despesa começa a ganhar mais representatividade no referido bloco, saindo de 1,9 milhões de reais em 2005 para 154 milhões de reais em 2016. Com isso, verificou-se um crescimento de 81 vezes no último ano em relação ao primeiro ano do período analisado.

O Gráfico 6 mostra a evolução dos recursos de assistência ao servidor em relação ao total aplicado no bloco de despesas Outras Despesas Correntes. 
Análise dos Recursos Financeiros Aplicados nas Instituiç̃es Federais de Educação Profissional, Científica e Tecnológica

\begin{abstract}
Gráfico 6 - Evolução dos recursos de Assistência ao Servidor comparados ao conjunto do bloco de Outras Despesas Correntes RFEPT e da RFEPCT (2000-2016) com todas as fontes de receitas. Valores em reais, a preços de janeiro de 2017 - IPCA
\end{abstract}

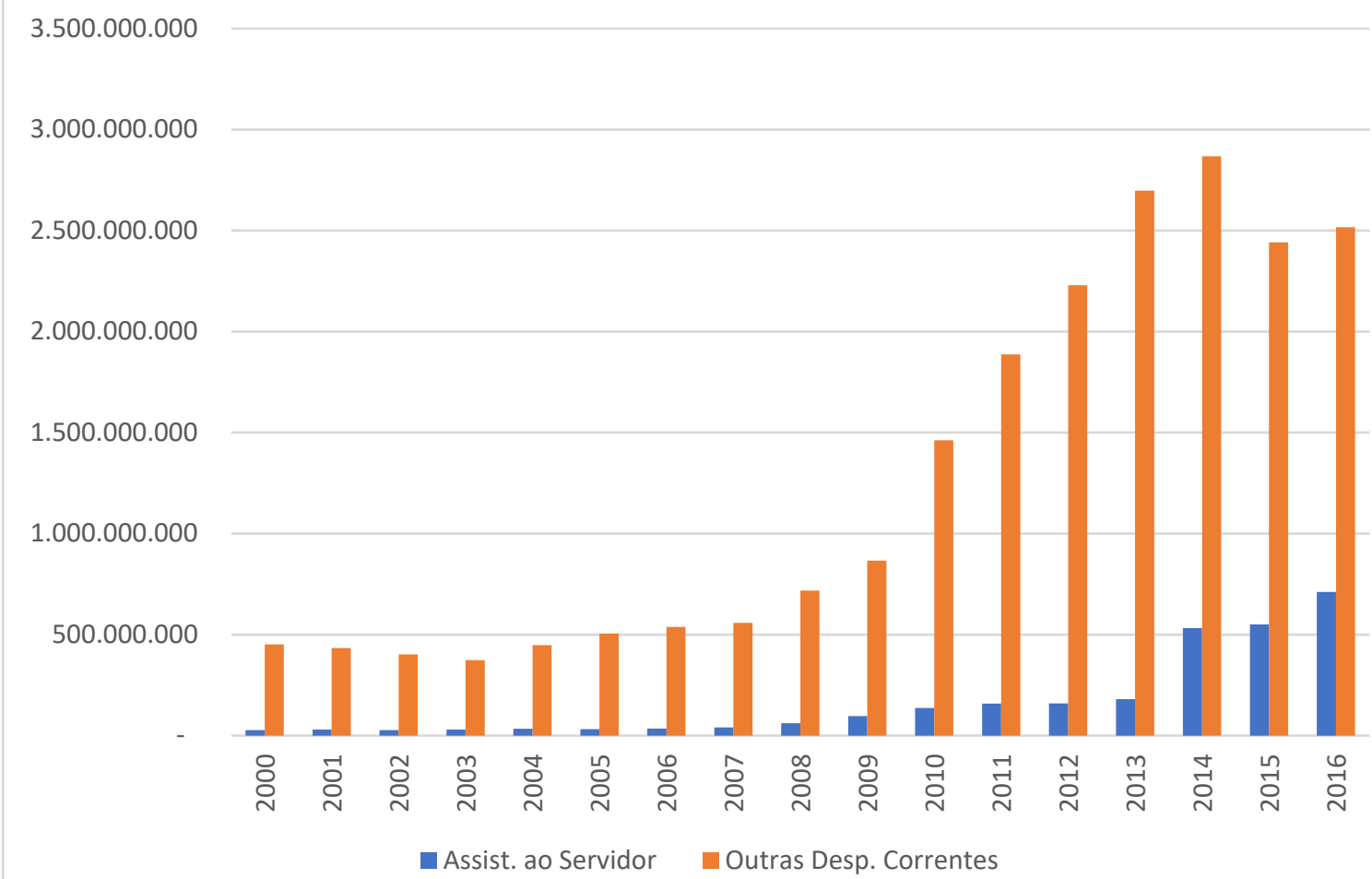

Fonte: Elaborada pelo autor com informações da Execução Orçamentária da União <www.camara.leg.br>.

A categoria Assistência ao Servidor, explicitada no Gráfico 6, agrega os elementos de despesas de Proteção e Benefícios ao Trabalhador (auxílios transporte, pré-escolar e alimentação) somados aos recursos de assistência médica e odontológica. O propósito da elaboração dessa categoria se explica pela necessidade de apreender a participação efetiva do total aplicado em assistência ao servidor no bloco de Outras Despesas Correntes. O montante de recursos apurados para a Assistência ao Servidor, entre os anos de 2000 e 2016, demonstra que $13 \%$ do total do referido bloco, ou 2,8 bilhões de reais, foram aplicados exclusivamente nessa categoria.

A partir desses dados é possível estabelecer comparações com o estudo realizado por Amaral (2003) para as Universidades Federais, que abrange o período de 1990 a 2002. Os dados disponibilizados pelo estudo indicam que, no último ano da pesquisa, somente os recursos aplicados na categoria Benefícios a Servidores (auxílio transporte, auxílio alimentação e auxílio pré-escolar) representaram $29 \%$ de todo o bloco de Outras Despesas Correntes. Segundo o autor, no primeiro ano do governo Fernando Henrique Cardoso (19952002), os reajustes lineares dos servidores públicos foram desativados, fazendo com que os benefícios passassem a atuar como salários indiretos.

Outro elemento de despesa computado no bloco de Outras Despesas Correntes, que ao longo do período entre 2000 e 2016 vai ganhando importância na totalidade dos recursos do referido bloco, é a Assistência ao Estudante da Educação Profissional e Tecnológica.

A evolução dos recursos entre os anos de 2000 e 2005, destinados à Assistência ao Estudante da EPT, apresenta estabilidade, com baixa representação no total do bloco. A partir 
Análise dos Recursos Financeiros Aplicados nas Instituiçoes Federais de Educação Profissional, Científica e Tecnológica

de 2006 verifica-se uma tendência de crescimento em ritmo moderado, partindo neste ano de 19,2 milhões e registrando, em 2008, 25,9 milhões de reais. De 2009 a 2014 observa-se um salto gigantesco, de 34,1 milhões, no primeiro ano, para 407,3 milhões de reais no último, crescendo, portanto, quase doze vezes em cinco anos. Em 2015, no contexto da crise financeira do Estado, registrou-se um recuo de 14,9\% em relação ao ano anterior e, em 2016, ampliou-se tal redução para $16,6 \%$ em relação ao melhor ano da assistência estudantil da Educação Profissional, Científica e Tecnológica Federal - 2014.

O Gráfico 7 apresenta a evolução da participação dos recursos destinados à Assistência ao Estudante da EPT em relação à totalidade dos recursos do bloco de Outras Despesas correntes entre os anos de 2000 e 2016.

Gráfico 7 - Evolução da participação dos recursos aplicados em Assistência ao Estudante RFEPT e da RFEPCT em relação ao conjunto do bloco de Outras Despesas Correntes (20002016) com todas as fontes de receitas. Valores em reais, a preços de janeiro de 2017 - IPCA

3.500 .000 .000

3.000 .000 .000

2.500 .000 .000

- Assist. ao Estudante

- Outras Desp. Correntes

2.000.000.000

1.500.000.000

1.000.000.000

500.000 .000

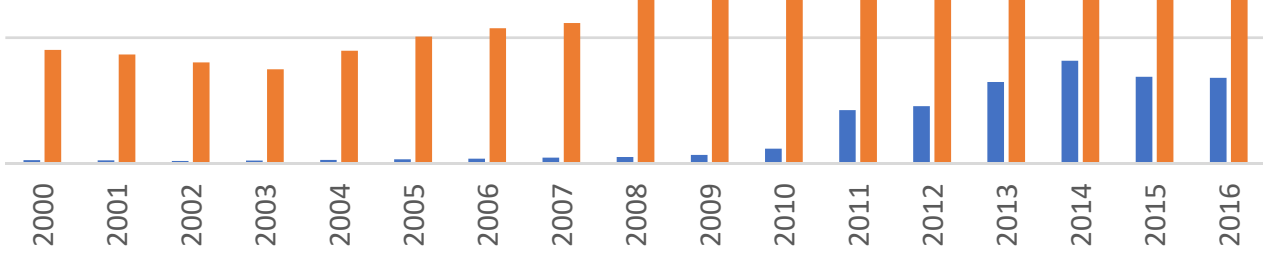

Fonte: Elaborada pelo autor com informações da Execução Orçamentária da União <www.camara.leg.br>

Conforme mostra o Gráfico 7, ao longo do período analisado a Assistência ao Estudante da EPT passa a ter maior participação no conjunto dos recursos aplicados no bloco de Outras Despesas Correntes. Em 2002, por exemplo, esse elemento de despesas representava apenas 3\% do total do bloco. Em 2011 avança oito pontos percentuais de participação, com 11\% do total. Em 2014, no melhor ano orçamentário da Rede Federal de EPCT, a Assistência ao Estudante da EPT salta para $14 \%$ de participação no total do bloco de Outras Despesas Correntes.

O aumento expressivo da participação da Assistência ao Estudante da EPT, no conjunto dos recursos aplicados no referido bloco, se explica pela implementação de uma política 
Análise dos Recursos Financeiros Aplicados nas Instituições Federais de Educação Profissional, Científica e Tecnológica

efetiva de assistência estudantil pelo governo federal, por meio do Decreto $n^{0} 7.234$ de 19 de julho de 2010, que instituiu do Programa Nacional de Assistência Estudantil (PNAES). Devese pontuar que a implementação dessa política se encontra respaldada pela Constituição Federal e pela LDB $n^{\circ}$ 9.394/1996, que no seu Artigo $3^{\circ}$ inciso I assevera que o ensino deverá ser ministrado observando-se o princípio de igualdade de condições de acesso e permanência para todos os educandos.

Nesse sentido, de acordo com o supracitado Decreto, a política do PNAES tem por objetivo enfrentar o complexo quadro de desigualdades que se reproduz no interior das instituições educacionais do País, e que redunda historicamente em altas taxas de evasão escolar. Desse modo, o programa está voltado ao atendimento de estudantes cuja renda familiar per capita não ultrapasse um salário mínimo e meio, os quais, após a comprovação do cumprimento das exigências legais, poderão ter acesso, inclusive de modo cumulativo, aos seguintes benefícios: moradia estudantil, alimentação, transporte, atenção à saúde, inclusão digital, cultura, esportes, creche, apoio pedagógico e acesso, participação e aprendizagem de estudantes com deficiência, transtornos globais do desenvolvimento e altas habilidades e superdotação.

A diversidade de modalidades de alcance da assistência estudantil da Rede Federal de EPCT a partir da política do PNAES, para além de justificar a ampliação substantiva dos recursos aplicados nesse elemento de despesa, também evidencia uma mudança de orientação por parte do Estado, na perspectiva de que a consolidação da escola pública federal, como locus de inclusão, passa necessariamente pela criação de condições de permanência dos estudantes.

Ademais, convém ressaltar, em que pese o impacto social e o significado qualitativo de uma política estatal consistente voltada à assistência estudantil, que o seu custo é relativamente baixo, quando se compara a outros elementos de despesas do conjunto do orçamento da Rede Federal. A título de ilustração do que se está afirmando, o total dos recursos aplicados na Assistência ao Estudante da Educação Profissional, Científica e Tecnológica no ano de maior "abundância" financeira, ou seja, no ano em que o Estado mais investiu nessa área (2014), representou apenas $3 \%$ do total do orçamento da Rede Federal de EPCT.

Ao longo do intervalo temporal analisado neste estudo, observou-se que, tanto as despesas correntes (pessoal e encargos sociais e outras despesas correntes), quanto às de capital (investimentos), se comportaram de modo a constituir dois importantes períodos no que diz respeito ao ritmo do volume de recursos movimentados.

O primeiro período compreende os anos de 1996 a 2004, caracterizado como de estabilidade, quando se analisa a evolução do conjunto das despesas com a manutenção RFEPT e da RFEPCT. Essa tendência se relaciona à orientação de política governamental que predominou ao longo dos dois governos de Fernando Henrique Cardoso, por meio da qual o Estado priorizava o desenvolvimento de ações do campo da Educação Profissional, a partir das parcerias público-privadas, que por sua vez eram implementadas por meio de programas governamentais (PEREIRA, 2018) que realizavam o financiamento em paralelo às transferências orgânicas da Rede Pública Federal. 
O Gráfico 8 apresenta a dinâmica da aplicação dos recursos com Investimentos - ou seja, na construção de novas edificações - dado o processo da expansão da Rede Federal, bem como na aquisição de equipamentos de laboratórios.

Gráfico 8 - Evolução dos recursos RFEPT e da RFEPCT aplicados em Investimentos (19962016) com todas as fontes de receitas. Valores em reais, a preços de janeiro de 2017 - IPCA

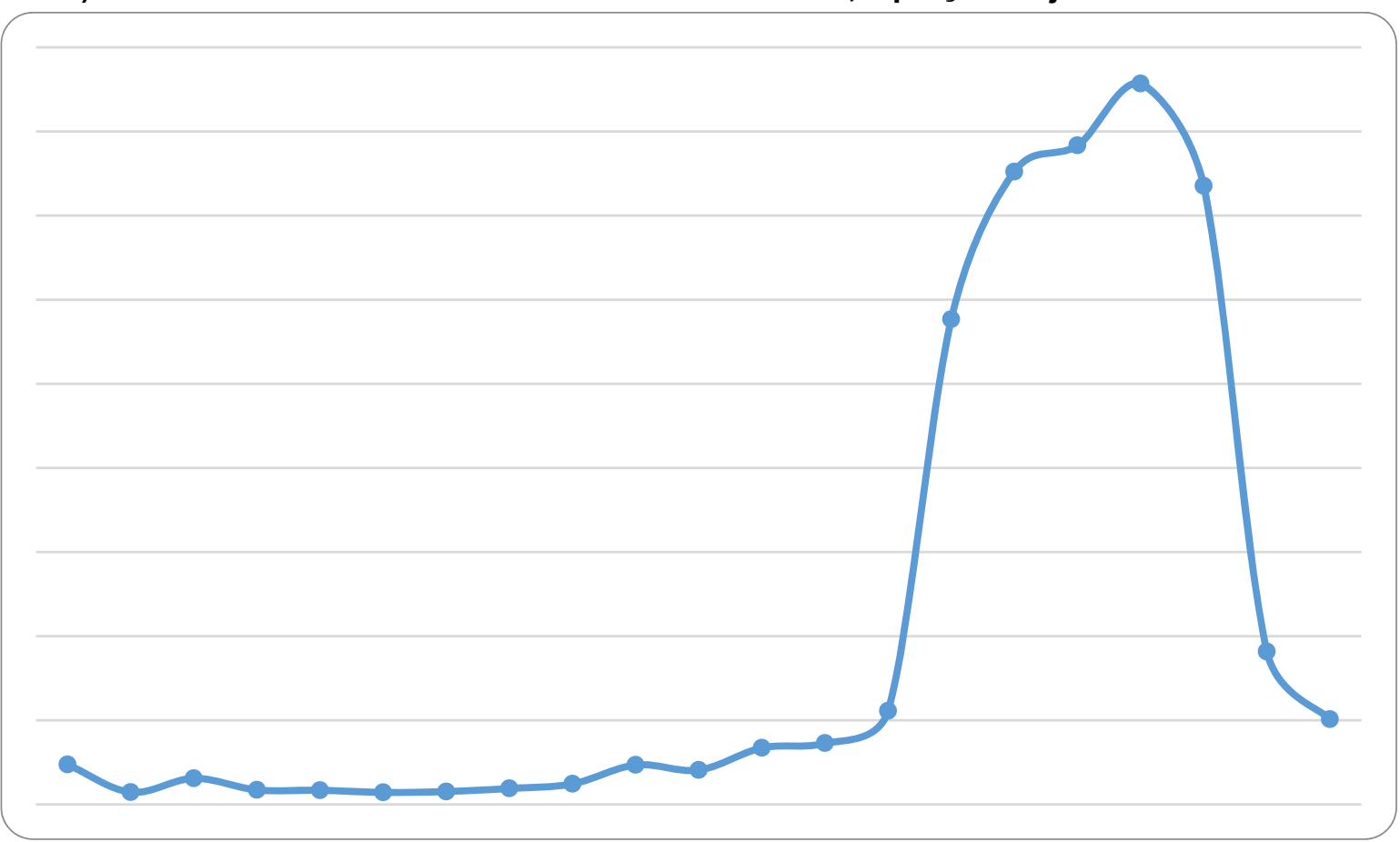

Fonte: Elaborada pelo autor com informações da Execução Orçamentária da União <www.camara.leg.br>

Deve-se ressaltar que, não obstante o movimento de "cefetização", ocorrido no final da década de 1990 e início dos anos 2000, produto da mobilização de segmentos de trabalhadores e gestores da EPT, houve o rebaixamento do estatuto dessas instituições, uma vez que se limitaram suas ofertas no âmbito do ensino superior ao nível tecnológico. Ademais, tal processo de transformação no interior da Rede não veio acompanhado por sua expansão, mas, pelo contrário, ocorreu alinhado à proibição legal da criação de novas Instituições Federais de Educação Profissional pelo governo federal. Com isso, verificou-se no intervalo de dez anos um crescimento próximo a $65 \%$ no volume de despesas, muito baixo a considerar-se a alta demanda por formação profissional no período.

O alcance de dez anos de estabilidade, na dinâmica das despesas com EPT, ocorreu porque nos três primeiros anos do primeiro governo Lula (2003-2006), em vez de ocorrer a expansão orçamentária, observou-se na verdade ligeira retração no ano de 2005 em relação ao ano de 2004, conforme indicou o Gráfico 1.

O segundo período, ilustrado pela ascensão nas curvas dos Gráficos 1, 2, 5 e 8, caracteriza-se por um intenso movimento de expansão das despesas do governo federal com a EPCT no âmbito da RFEPT e da RFEPCT, e compreende os anos que vão de 2005 a 2014. É importante observar, conforme consta na Tabela 1 e Gráfico 8, que nesse período as despesas de capital (investimento) crescem em ritmo mais intenso que as despesas correntes. Entre os anos de 2005 e 2013 as despesas de investimentos cresceram mais de 18 vezes, enquanto as despesas correntes cresceram 3,5 vezes, indicando um importante 
processo de expansão física da Rede Federal, pela aquisição e construção de prédios, laboratórios e equipamentos necessários ao funcionamento das centenas de unidades inauguradas ao longo das diversas fases do processo de expansão da Rede.

Esse processo de expansão da Rede Federal pode ser bem representado no Gráfico 8, o qual apresenta a dinâmica das despesas de capital, ou seja, na construção e aparelhamento de novas unidades como também na expansão física e de laboratórios ocorrida nas unidades antigas, ao longo desse denominado segundo período.

É importante assinalar que, conforme indica o referido gráfico, diversamente do que ocorre em relação às despesas correntes (Gráficos 2 e 3), as despesas de investimentos não apresentam um ritmo sustentado e estável de crescimento ${ }^{1}$ ao longo de todo o processo de expansão, que ainda no ano de 2019 se encontra em andamento. Por se tratar de despesas relacionadas a bens de capital, sua oscilação ocorre a partir das demandas de projetos de expansão física da Rede, o que faz com que a realização desse tipo de despesa esteja sujeita a maior ou menor disponibilidade de recursos financeiros por parte do Tesouro Nacional.

Desse modo, observou-se, já nos primeiros anos de expansão da RFEPT e da RFEPCT, um ritmo exponencial de crescimento, chegando a aumentar em pouco mais de duas vezes o quantitativo de recursos entre 2005 e 2009. Posteriormente, de 2009 a 2013, notou-se um salto espetacular, saindo de 222 milhões de reais no primeiro ano para 1,7 bilhão de reais no último (ver Gráfico 8), assinalando o auge do processo de expansão física da Rede. No ano seguinte observou-se um recuo para 1,4 bilhões de reais e, em 2015, com o agravamento da crise econômica e o consequente contingenciamento de recursos do Ministério da Educação, o investimento desabou para 363 milhões de reais. Em 2016 esses recursos foram reduzidos para 206 milhões de reais, o menor nível de investimentos desde o ano de 2009, repercutindo de modo negativo no ritmo de entrega das obras, muitas delas paralisadas por tempo indeterminado. De acordo com levantamento do Ministério da Educação (BRASIL, 2016b), publicado em julho de 2016, havia naquele mês 462 obras paralisadas no âmbito da Rede Federal de Educação Profissional, Científica e Tecnológica.

A inexpressividade relativa dos valores registrados nas Inversões Financeiras, conforme Tabela 1, está relacionada às exigências do governo federal quando da realização dos projetos de construção para a expansão da Rede Federal, dentre as quais condicionava a construção de determinada unidade exigindo como contrapartida a doação dos terrenos pelos governos municipais, como se pode observar na notícia do jornal eletrônico G1 do dia 27 de março de 2012, cuja reportagem apresenta o seguinte título: Sete municípios podem ganhar unidade do IFPE se doarem terrenos. Outro jornal eletrônico do estado de Pernambuco, com reportagem do dia 05 de março de 2012, traz o seguinte título em matéria sobre a expansão: Prefeito não doa terreno e Palmares perde IFPE.

Há, contudo, casos em que as disputas entre prefeituras pelo privilégio de sediar um campus do Instituto Federal resultaram na doação não apenas de terrenos, mas também de prédios, a exemplo da Prefeitura Municipal de Uruaçu, no Norte de Goiás, na qual o poder público municipal realizou a doação dos prédios das sedes da Prefeitura e da Câmara

1 Tem-se claro que tão logo cesse o processo de expansão física da Rede, as despesas de investimentos tendem a observar importante redução, no entanto, a não finalização das obras indica uma abrupta ruptura nesse tipo de despesa, sinalizando dificuldades no financiamento das ações. 
Municipal ${ }^{2}$, que seriam posteriormente adaptados para a condição de prédio escolar ${ }^{3}$. Há ainda inúmeros casos em que os governos municipais ofereciam, na condição de empréstimo, estruturas escolares para o funcionamento imediato do Instituto Federal até que as edificações próprias fossem inauguradas.

Também se verificou a existência de acordos entre prefeituras e Institutos Federais em que, além da doação de terrenos, os governos municipais se responsabilizavam por parte da manutenção dos edifícios ${ }^{4}$, a exemplo dos gastos de Outras Despesas Correntes, tais como água e energia. Fica evidenciado que, tanto os poderes locais quanto o Ministério da Educação, sabiam claramente da importância, para os municípios, dos Institutos Federais, como fator de desenvolvimento local e regional e possivelmente - não menos importante - de futuros dividendos eleitorais, a ponto de se estabelecer determinados níveis de "barganha", as quais influenciariam na redução das despesas por parte do governo federal, sobretudo aquelas relacionadas aos bens de capital.

\section{Conclusões}

Ao longo dos anos 1990 assistiu-se à implementação de um conjunto de reformas no âmbito do Estado brasileiro. No aspecto estritamente econômico verificou-se a redução do tamanho do Estado pela venda de seus principais e mais estratégicos empreendimentos econômicos. Também as reformas financeiras trataram de criar um ambiente propício à atuação dos interesses empresariais e financeiros, sobretudo no âmbito dos mercados de capitais, repercutindo negativamente na participação do emprego industrial no País.

Os ajustes macroeconômicos, realizados nesse contexto, implicaram numa mudança de perspectiva da relação do fundo público com os gastos sociais em educação. A dinâmica dos recursos aplicados nas Instituições Federais de Educação Profissional e Tecnológica, nos nove primeiros anos deste estudo, é bem representativa da estagnação do gasto público com educação no País no contexto supramencionado. De fato, assistia-se naquela conjuntura um contínuo processo de sucateamento tanto no âmbito da Educação Profissional Federal como também nas Universidades Públicas Federais, realidade que resultaria em políticas que apresentavam como finalidade última - ainda que não publicada - o processo de privatização das instituições públicas, e, por conseguinte, em enorme ônus para as famílias no que tange à educação dos indivíduos.

A substituição da hegemonia neoliberal por um governo de conciliação de classes, a partir do ano de 2002, resultou numa relativa estabilização da sociedade. Durante mais de uma década verificou-se um processo de repactuação de direitos sociais, mediante os quais parte expressiva da população trabalhadora logrou importantes progressos econômicos. Nesse contexto, assistiu-se a drástica redução dos níveis de miséria e pobreza e a ascensão social de milhões de indivíduos por meio de políticas de valorização do Salário Mínimo, dentre outras.

2 O Jornal Eletrônico Diário do Norte noticiou, no dia 17 de maio de 2009, a doação do prédio da Câmara Municipal de Uruaçu, para incorporação ao patrimônio do IFG, em face da abertura do Curso de Engenharia Civil no Campus Uruaçu.

3 Nesta cidade foi instalado o Campus Uruaçu, do Instituto Federal de Goiás.

4 A exemplo do que ocorreu no Campus Senador Canedo, do Instituto Federal de Goiás. 
Análise dos Recursos Financeiros Aplicados nas Instituições Federais de Educação Profissional, Científica e Tecnológica

No campo da educação verificou-se a implementação de um conjunto de medidas que, embora complexas e por vezes contraditórias, significou a ampliação do financiamento público de projetos de inclusão educacional em todos os níveis e modalidades, os quais, de um lado, implicaram no fortalecimento da educação empresarial/privada com recursos do fundo público, e, de outro, em um sólido processo de expansão da rede pública federal de educação profissional e tecnológica, como também pela criação de um relevante número de novas vagas na universidade pública por meio da criação de novas universidades e novos campi universitário.

Como resultado do movimento de expansão, observou-se fenomenal elevação do gasto público com a Educação Profissional e Tecnológica, conforme se pretendeu demonstrar neste estudo. Tal movimento tem início ainda em 2005 e se intensifica com a transformação da antiga Rede Federal em Rede Federal de Educação Profissional, Científica e Tecnológica no ano de 2008. Como resultado dessa política de Estado para a modalidade, verificou-se, desde o primeiro ano de funcionamento da nova Rede, um salto substantivo no número de matrículas em todos os níveis e modalidades.

Tão logo os efeitos de exaustão do modelo econômico baseado preponderantemente na exportação de commodities se evidenciou, ressurgiu também a instabilidade social e política, a qual trouxe consigo uma grave crise de hegemonia no País, a ponto de comprometer a manutenção das políticas de inclusão tão marcantes na última década. A partir de então assiste-se à retomada da hegemonia neoliberal, que, por meio da desestruturação da esfera pública, tem implicado na ameaça da retirada das conquistas históricas dos trabalhadores, ante as furiosas investidas do capital em vista do controle do fundo público.

$\mathrm{Na}$ atual conjuntura, a redução do orçamento da Rede Federal e os subsequentes contingenciamentos de recursos do conjunto das Instituições, observados nos dois últimos anos deste estudo, podem se constituir em indicativos do risco de grandes retrocessos para o campo da Educação Profissional, Científica e Tecnológica pública. Notam-se possibilidades de ruptura com um projeto educacional com consistente potencial emancipatório, como também se percebem aberturas a projetos de privatização dos serviços ofertados nessas instituições.

\section{Referências}

AMARAL, Nelson Cardoso. Financiamento da Educação Superior: Estado X Mercado. São Paulo: Cortez; Piracicaba: Editora UNIMEP, 2003.

AMARAL, Nelson Cardoso; PINTO, José Marcelino de Rezende. O financiamento das IES brasileiras em 2005: recursos públicos, privados e custo dos alunos. Série-Estudos Periódico do Programa de Pós-Graduação em Educação da UCDB, Campo Grande, n. 30, p. 51-70, jul./dez. 2010.

BRASIL. Lei n 9394, de 20 de dezembro de 1996. Estabelece as Diretrizes e Bases da Educação Nacional. Diário Oficial da União, Brasília, 1996. Disponível em: <http://www.planalto.gov.br/ccivil_03/leis/L9394.htm>. Acesso em: 20 jun. 2017.

BRASIL. Decreto-Lei $n^{\circ} 2.208 / 97$, de 17 de abril de 1997. Regulamenta o $\S 2^{\circ}$ do art. 36 e os arts. 39 a 42 da Lei $n^{\circ}$ 9.394, de 20 de dezembro de 1996, que estabelece as diretrizes e 
bases da educação nacional. Diário Oficial da União, Brasília, 1997a. Disponível em: <http://www.planalto.gov.br/ccivil_03/decreto/D2208.htm>. Acesso em: 28 jan. 2017.

BRASIL. Decreto $n^{\circ} 2.271$ de 7 de julho de 1997. Dispõe sobre a contratação de serviços pela Administração Pública Federal direta, autárquica e fundacional e dá outras providências. Diário Oficial da União, Brasília, 1997b. Disponível em: <http://www. planalto.gov.br/ccivil_03/decreto/d2271.htm>. Acesso em: 04 nov. 2017.

BRASIL. Decreto $n^{\circ} 5.154$, de 23 de julho de 2004. Regulamenta o $§ 20$ do art. 36 e os arts. 39 a 41 da Lei no 9.394, de 20 de dezembro de 1996, que estabelece as diretrizes e bases da educação nacional, e dá outras providências. Diário Oficial da União, Brasília, 2004. Disponível em: <http://www.planalto.gov.br/ccivil_03/_ato2004-2006/2004/decreto/d5 154.htm>. Acesso em: 20 set. 2017.

BRASIL. Lei $n^{\circ}$ 11.892, de 29 de dezembro de 2008. Institui a Rede Federal de Educação Profissional, Científica e Tecnológica, cria os Institutos Federais de Educação, Ciência e Tecnologia, e dá outras providências. Diário Oficial da União, Brasília, 30 dez. 2008. P. 1. Disponível em: <http://www.planalto.gov.br/ccivil_03/_ato2007-2010/2008/lei//11892.htm>. Acesso em: 6 fev. 2016

BRASIL. Decreto $n^{\circ}$ 7.234. Dispõe sobre o Programa Nacional de Assistência Estudantil-PNAES. Diário Oficial da União, Brasília, 2010. Disponível em: <http://www.planalto.gov.br/ccivil_03/_ato2007-2010/2010/decreto/d7234.htm>. Acesso em: 11 nov. 2017.

BRASIL. Lei $n^{\circ} 11.741$, de 16 de julho de 2012. Altera dispositivos da Lei $n^{\circ} 9.394$, de 20 de dezembro de 1996, que estabelece as diretrizes e bases da educação nacional, para redimensionar, institucionalizar e integrar as ações da educação profissional técnica de nível médio, da educação de jovens e adultos e da educação profissional e tecnológica. Diário Oficial da União, Brasília, 2012a. Disponível em: <http://www.planalto.gov.br/ccivil _03/_Ato2007-2010/2008/Lei/L11741.htm\#art1>. Acesso em: 03 nov. 2017.

BRASIL. Lei № 12.772, de 28 de dezembro de 2012, que, Dispõe sobre a estruturação do Plano de Carreiras e Cargos de Magistério Federal; sobre a Carreira do Magistério Superior, de que trata a Lei no 7.596, de 10 de abril de 1987; sobre o Plano de Carreira e Cargos de Magistério do Ensino Básico, Técnico e Tecnológico e sobre o Plano de Carreiras de Magistério do Ensino Básico Federal, de que trata a Lei $n^{\circ} 11.784$, de 22 de setembro de 2008; sobre a contratação de professores substitutos, visitantes e estrangeiros, de que trata a Lei no 8.745 de 9 de dezembro de 1993. Diário Oficial da União, Brasília, 2012b. Disponível em: <http://www.planalto.gov.br/ccivil_03/_Ato2011-2014/2012/Lei/L12772.htm>. Acesso em: 20 jun. 2017.

BRASIL. Lei. $N^{0} 13.325$, de 29 de julho de 2016, que, altera a remuneração, as regras de promoção, as regras de incorporação de gratificação de desempenho a aposentadorias e pensões de servidores públicos da área da educação, e dá outras providências. Diário Oficial da União, Brasília, 2016a. Disponível em: http://www.planalto.gov.br/ccivil_03/Ato20152018/2016/Lei/L13325.htm acesso em: 20 de junho de 2018.

BRASIL. Ministério da Educação. Relatório de Gestão Consolidado 2015. Brasília: Secretaria Executiva, 2016b. 
Análise dos Recursos Financeiros Aplicados nas Instituições Federais de Educação Profissional, Científica e Tecnológica

GRABOWSKI, Gabriel. Financiamento da Educação Profissional no Brasil: contradições e desafios. 2010. Tese (Doutorado em Educação) - Faculdade de Educação, Universidade Federal do Rio Grande do Sul, Porto Alegre, 2010.

HARVEY, David. Condição Pós-Moderna. 25. ed. São Paulo: Edições Loyola, 2014.

OLIVEIRA, Euclides. Câmara aprova doação de sede. Diário do Nordeste online, Porangatu, 17 maio 2009. Disponível em: <http://www.jornaldiariodonorte.com.br/noticias/camaraaprova-doacao-de-sede-3648>. Acesso em: 02 fev. 2018.

PEREIRA, Josué Vidal. O financiamento da Rede Federal de Educação Profissional, Científica e Tecnológica. 2018. Tese (Doutorado em Educação) - Universidade Federal de Goiás, Goiânia, 2018.

PREFEITO NÃO DOA terreno e Palmares perde IFPE. NE10, Recife, 05 mar. 2012. Disponível em: $\quad<$ https://ne10.uol.com.br/canal/interior/zona-da-mata/noticia/2012/03/05/prefeito-naodoa-terreno-e-palmares-perde-ifpe-330296.php>. Acesso em: 02 fev. 2018.

RODRIGUES, Romir de Oliveira. No caminho do Curupira: O Programa Nacional de Acesso ao Ensino Técnico e Emprego - Pronatec - e as relações público-privadas. 2017. Tese (Doutorado em Educação) - Universidade Federal do Rio Grande do Sul, Porto Alegre, 2017.

SETE MUNICÍPIOS podem ganhar unidade do IFPE se doarem terrenos. G1, globo.com, Pernambuco, 27 mar. 2012. Disponível em: <http://g1.globo.com/pernambuco/ noticia/2012/03/sete-municipios-podem-ganhar-unidade-do-ifpe-se-doarem-terrenos.html>.

Acesso em: 02 fev. 2018.

Josué Vidal Pereira é professor no Instituto Federal de Goiás - Campus Goiânia. Doutorando no Programa de Pós-Graduação em Educação da Faculdade de Educação da Universidade Federal de Goiás (UFG). Atualmente está envolvido em Projetos de Pesquisas na área de Financiamento da Educação Profissional.

ORCID: http://orcid.org/0000-0003-0210-3137

E-mail: josuevp8@gmail.com 


\section{Editores do volume 9}

José Marcelino de Rezende Pinto - Universidade de São Paulo, São Paulo/SP, Brasil

Nalú Farenzena - Universidade Federal do Rio Grande do Sul, Porto Alegre/RS, Brasil

\section{Comitê Editorial}

José Marcelino de Rezende Pinto - Universidade de São Paulo, Brasil

Juca Gil - Universidade Federal do Rio Grande do Sul, Brasil

Theresa Adrião - Universidade Estadual de Campinas, Brasil Ângelo

Ricardo de Souza - Universidade Federal do Paraná, Brasil

Márcia Aparecida Jacomini - Universidade Federal de São Paulo, Brasil

\section{Conselho Editorial}

\section{Alejandro Morduchowicz}

Universidad Pedagógica, Provincia de Buenos Aires, Argentina

Fernanda Saforcada

Universidade de Buenos Aires, Argentina

Jacques Velloso

Universidade de Brasília, Brasil

João Monlevade

Senado Federal, Brasil

Jorge Abrahão de Castro

Instituto de Pesquisa Econômica Aplicada / IPEA, Brasil

Juca Gil

Universidade Federal do Rio Grande do Sul, Brasil

Lisete Regina Gomes Arelaro

Universidade de São Paulo, Brasil

Luis Carlos Sales

Universidade Federal do Piauí, Brasil

Luiz de Sousa Junior

Universidade Federal da Paraíba, Brasil

Luiz Fernandes Dourado

Universidade Federal de Goiás, Brasil

Magna França

Universidade Federal do Rio Grande do Norte, Brasil

\section{Maria Beatriz Luce}

Universidade Federal do Pampa, Brasil

Universidade Federal do Rio Grande do Sul, Brasil

Marcos Edgar Bassi

Universidade Federal de Santa Catarina, Brasil

\author{
Maria Dilnéia Espíndola Fernandes \\ Universidade Federal de Mato Grosso do Sul, Brasil \\ Nalú Farenzena \\ Universidade Federal do Rio Grande do Sul, Brasil \\ Nelson Cardoso do Amaral \\ Universidade Federal de Goiás, Brasil \\ Nicholas Davies \\ Universidade Federal Fluminense, Brasil \\ Rosana Evangelista Cruz \\ Universidade Federal do Piauí, Brasil \\ Rosana Gemaque \\ Universidade Federal do Pará, Brasil \\ Robert E. Verhine \\ Universidade Federal da Bahia, Brasil \\ Romualdo Portela de Oliveira \\ Universidade de São Paulo, Brasil \\ Theresa Adrião \\ Universidade Estadual de Campinas, Brasil \\ Tristan McCowan \\ University of London, Reino Unido \\ Vera Jacob \\ Universidade Federal do Pará, Brasil \\ Vera Peroni \\ Universidade Federal do Rio Grande do Sul, Brasil \\ Vitor Henrique Paro \\ Universidade de São Paulo, Brasil
}

\section{Equipe editorial}

Apoio ao Comitê Editorial: Patrícia Balthazar Garcia

Diagramação, Revisão de português e normalização: Edson Leonel de Oliveira

Revisão de inglês: Ananyr Porto Fajardo 